\title{
SIMULASI PENGARUH ARUS TERHADAP SIMPANGAN DAN EFISIENSI SILT SCREEN
}

\author{
David S.V.L Bangguna ${ }^{1}$, Irnovia B. Pakpahan ${ }^{2}$, Ifiginia ${ }^{3}$ \\ ${ }^{1}$ Jurusan Teknik Sipil, Universitas Sintuwu Maroso, Poso 94619 \\ E-mail : banggunaa@gmail.com \\ ${ }^{2}$ Jurusan Teknik Sipil, Universitas Sintuwu Maroso, Poso 94619 \\ E-mail : pakpahanirnovia@gmail.com \\ ${ }^{3}$ Jurusan Teknik Sipil, Universitas Sintuwu Maroso, Poso 94619 \\ E-mail :feychloe@gmail.com
}

\begin{abstract}
ABSTRAK
Slit screen yaitu tirai tidak kaku (screen) yang berfungsi untuk menahan laju sedimen khususnya lumpur (silt) yang membuat alur pelayaran di kolam labuh menjadi dangkal akibat siltasi (siltation). Silt screen dapat dibuat dari bahan geotekstil yang berfungsi sebagai penahan sedimen yang diberi pelampung dan pemberat di bawahnya. Dari simulasi silt screen menunjukkan bahwa pengikatan pelampung memberikan simpangan yang lebih rendah 21,15\% sampai dengan 33,85\% dengan efisiensi $53,85 \%$ sampai dengan $84,23 \%$, jika dibandingkan tanpa pengikatan pelampung simpangan yang terjadi 50,00\% sampai dengan $72,69 \%$ dengan efisiensi 30,19\% sampai dengan 71,92\%. Pelampung yang terlalu berat akan mengakibatkan perubahan tinggi silt screen arah vertikal menjadi rendah, sehingga fungsi silt screen tidak akan maksimal dalam aplikasinya sebagai penjaring sedimen.
\end{abstract}

Kata Kunci: silt screen, simpangan, efisiensi

\section{ABSTRACT}

Slit screen is a screen that is not rigid (screen) which functions to hold the rate of sediment, especially mud (silt), which makes the shipping channel in the anchoring pond shallow due to siltation. Silt screens can be made of geotextile material which functions as a sediment barrier which is given a float and a weight under it. From the simulation of the silt screen, it shows that the binding of the buoys provides a lower shifting of $21.15 \%$ to $33.85 \%$ with an efficiency of $53.85 \%$ to $84.23 \%$, when compared without binding the float, the shifting occurs $50.00 \%$ to $72.69 \%$ with an efficiency of $30.19 \%$ to $71.92 \%$. The float that is too heavy will result in a change in the height of the silt screen in the vertical direction to a low one, so that the silt screen function will not be maximal in its application as a sediment filter.

Keywords: silt screen, shifting, efficiency

\section{PENDAHULUAN}

Salah satu alternatif penanggulangan sedimentasi di kolam labuh yang landai dan berlumpur yaitu menggunakan silt screen. Slit screen yaitu tirai tidak kaku (screen) yang berfungsi untuk menahan laju sedimen khususnya lumpur (silt) yang membuat alur pelayaran di kolam labuh menjadi dangkal akibat siltasi (siltation) [1].

Simulasi silt screen terhadap sedimen telah banyak dilakukan, seperti simulasi silt screen dalam menahan laju sedimen suspensi akibat pengerukan di alur pelayaran [2], simulasi hubungan transport sedimen terhadap kedalaman efektif screen [3], analisis perilaku sedimen tersuspensi di sekitar silt screen [4], simulasi fenomena hidraulik silt screen[5], analisis penerapan silt screen gantung untuk menahan laju sedimen suspensi akibat kegiatan reklamasi [6].

Silt screen dapat dibuat dari bahan geotekstil yang berfungsi sebagai penahan sedimen yang diberi pelampung dan pemberat di bawah. Silt screen akan berfungsi maksimal dalam menjaring sedimen apabila simpangannya kecil. Pengertian simpangan silt screen disini adalah perpindahan posisi pelampung searah arus. Simpangan silt screen ini penting untuk dianalisis, apabila simpangan silt screen ini tidak dapat dikendalikan maka screen tidak berfungsi menahan sedimen di alur pelayaran. Agar silt screen ini dapat berfungsi dengan baik perlu dirancang dengan tepat terutama yang berkaitan dengan perilaku pengaruh arus pada simpangan silt screen dan gaya yang ditimbulkan pada silt screen. Penelitian ini bertujuan untuk menganalisis pengaruh arus terhadap simpangan dan efisiensi silt screen. 


\section{TEORI MODEL SILT SCREEN}

\subsection{Simpangan dan Efisiensi Silt Screen}

Simpangan didefinisikan dari hasil bagi perubahan jarak simpangan arah horizontal (X') dengan tinggi silt screen (h) dalam persen. Sedangkan efisiensi silt screen didefinisikan dari hasil bagi perubahan tinggi silt screen setelah terkena arus (h') dengan tinggi silt screen $(\mathrm{h})$ dalam persen. Simpangan silt screen merupakan fungsi dari kecepatan arus $(\mathrm{U})$, gaya arus $\left(\mathrm{F}_{\mathrm{U}}\right)$, diameter pelampung (D), gaya apung pelampung $\left(\mathrm{F}_{\mathrm{BP}}\right)$, luas proyeksi silt screen $\left(\mathrm{A}_{\mathrm{P}}\right)$, kedalaman air $(\mathrm{d})$, tinggi silt screen $(\mathrm{h})$, dan pengaruh pengikatan pelampung silt screen. Hubungan parameter terebut dapat dinyatakan sebagai fungsi sebagai berikut:

$$
\begin{array}{ll}
\text { Simpangan silt screen } & =\mathrm{f}\left(\mathrm{Fv}, \mathrm{F}_{\mathrm{U}}, \mathrm{D}, \mathrm{h}, \mathrm{d}, \mathrm{X}^{\prime}\right) \\
\text { Efisiensi silt screen } & =\mathrm{f}\left(\mathrm{Fv}, \mathrm{F}_{\mathrm{U}}, \mathrm{D}, \mathrm{h}, \mathrm{d}, \mathrm{h}^{\prime}\right)
\end{array}
$$

Dan hubungan antara variabel ditunjukkan dalam Gambar 1.

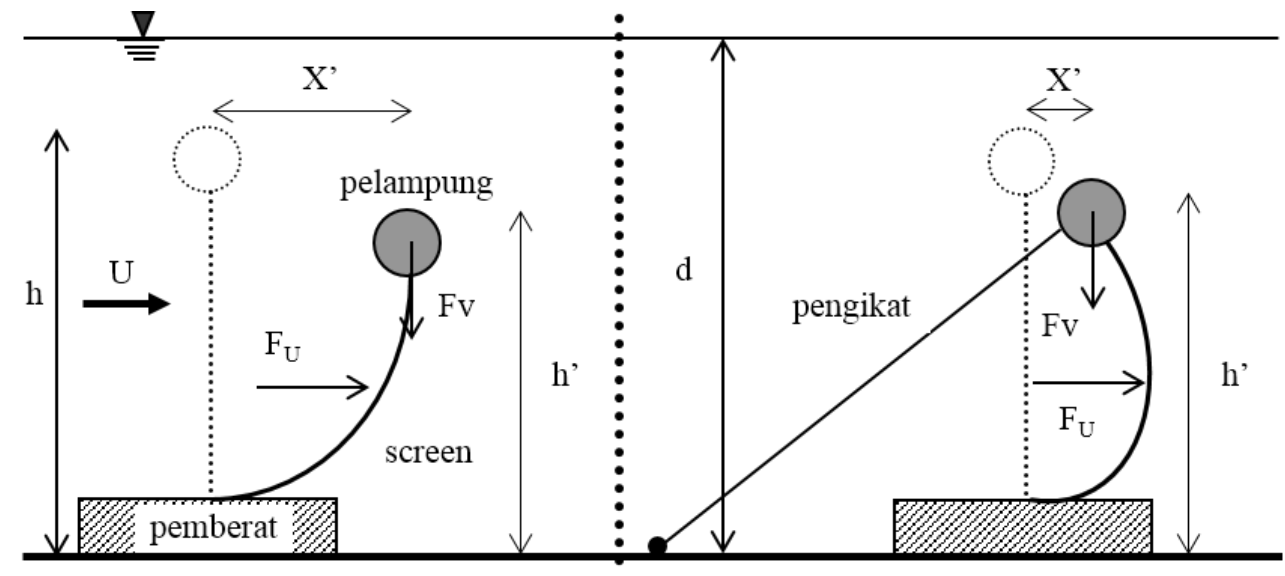

$\begin{array}{ll}\text { (a) Tanpa Pengikatan Pelampung } & \text { (b) Dengan Pengikatan Pelampung }\end{array}$

$$
\text { Gambar 1. Model Silt Screen }
$$

Besarnya simpangan dan efisiensi silt screen ditulis dalam persamaan berikut:

$$
\begin{array}{ll}
\text { Simpangan silt screen } & =\frac{\mathrm{X}^{\prime}}{\mathrm{h}} \times 100 \% \\
\text { Efisiensi silt screen } & =\frac{\mathrm{h}^{\prime}}{\mathrm{h}} \times 100 \%
\end{array}
$$

dengan $\mathrm{h}$ adalah tinggi silt screen, $\mathrm{h}$ ' adalah perubahan tinggi silt screen setelah terkena arus, dan $\mathrm{X}$ ' adalah simpangan silt screen.

\subsection{Gaya Pengikat pelampung}

Gaya pengikat pelampung $\left(\mathrm{F}_{\mathrm{T}}\right)$ didefinisikan sebagai gaya yang bekerja pada pengikat pelampung yang dihitung dari hasil bagi gaya vertikal $(\mathrm{Fv})$ dengan sudut yang terbentuk antara gaya vertikal $(\mathrm{Fv})$ dan gaya pengikat pelampung $\left(\mathrm{F}_{\mathrm{T}}\right)$ yaitu $\cos \theta$ seperti pada Gambar 2. 


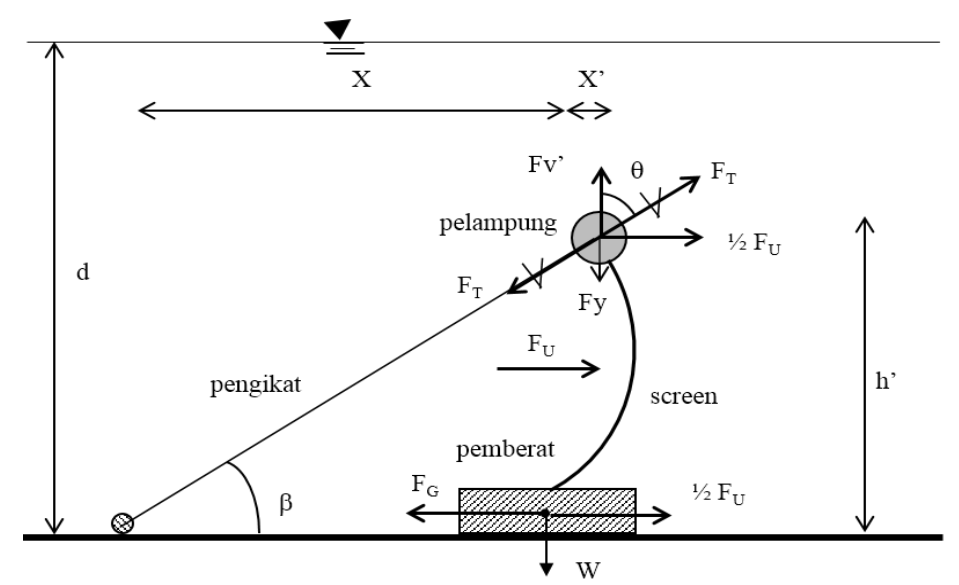

Gambar 2. Gaya Pengikat Pelampung

Besarnya gaya pengikat pelampung adalah:

$$
\begin{aligned}
& \mathrm{F}_{\mathbf{T}}=\frac{1 / 2 \mathrm{~F}_{\mathrm{U}}}{\cos \beta} \\
& \mathrm{Fy}_{\mathrm{y}}=\mathrm{FV}-\mathrm{F}_{\mathrm{T}} \cos \theta
\end{aligned}
$$

dengan $\beta$ adalah sudut antara pengikat dengan dasar saluran, $\theta$ adalah sudut antara gaya vertikal dengan gaya pengikat pelampung, $\mathrm{F}_{\mathrm{U}}$ adalah gaya arus, $\mathrm{F}_{\mathrm{T}}$ adalah gaya pengikat pelampung, $\mathrm{Fv}$ adalah gaya vertikal pelampung, dan $\mathrm{Fy}$ adalah gaya proyeksi screen.

\section{METODE PENELITIAN}

Simulasi pengaruh arus terhadap simpangan dan efisiensi silt screen dilaksanakan di Laboratorium Hidraulika dan Hidrologi Pusat Studi Ilmu-ilmu Teknik Universitas Gajah Mada, Yogyakarta. Fasilitas yang digunakan dalam simulasi yaitu glass sided fixed bed tilting flume yang mempunyai panjang efektif $22 \mathrm{~m}$, lebar saluran $0,3 \mathrm{~m}$ dan tinggi saluran $0,6 \mathrm{~m}$. Alat ini biasa digunakan untuk simulasi model bangunan air. Dasar dari flume dari baja dan dinding dari bahan acrylic. Dasar dan dinding flume disangga oleh rangka baja pada jarak yang teratur, alat ini dilengkapi pengatur sirkulasi air (Gambar 3). Kecepatan arus diukur menggunakan current meter.

Model silt screen terdiri dari pelampung yang terbuat dari PVC dan kayu, screen terbuat dari kain, dan pemberat yang dibuat sedemikian rupa sehingga tidak bergeser (Gambar 4). Model silt screen dibuat 6 macam dengan beberapa variasi simulasi (Tabel 1). Dalam simulasi ini tidak menggunakan sedimen. Simulasi ini hanya mengamati simpangan silt screen akibat arus. Sebelum simulasi dimulai, terlebih dahulu dilakukan kalibrasi kecepatan arus terhadap bukaan katup pipa yang mengalirkan air dari bak penampungan ke dalam flume. Kalibrasi ini bertujuan untuk mengetahui berapa kecepatan arus yang dihasilkan dari putaran katup pipa. Sehingga saat simulasi tidak perlu dilakukan pengukuran kecepatan arus lagi tetapi cukup dengan membuka katup pipa.

Simulasi pengaruh arus pada simpangan silt screen dilakukan dengan mengamati simpangan silt screen yang terjadi dan penggambaran profil simpangan silt screen pada plastik transparan bergaris yang ditempatkan di dinding sebelah luar flume, serta mengamati parameter-parameter berpengaruh dalam simulasi yaitu: kecepatan arus (U), ukuran diameter pelampung (D), gaya apung pelampung $\left(\mathrm{F}_{\mathrm{BP}}\right)$, tinggi model $(\mathrm{h})$, jarak simpangan $\left(\mathrm{X}^{\prime}\right)$, tinggi model setelah terkena arus (h'), kedalaman air (d), dan pengaruh pengikatan pelampung. Pelaksanaan simulasi simpangan silt screen dapat dilihat dalam Gambar 5 dan 6 .

Simulasi dimulai dengan langkah berikut: (1) Model diletakkan pada dasar flume yang telah diisi air pada ketinggian yang telah ditentukan, (2) Pompa dijalankan untuk menggerakkan sirkulasi air dari bak penampungan ke dalam flume, (3) Katup pipa dibuka dengan putaran tertentu, (4) Setelah aliran stabil, simpangan silt screen digambar pada plastik transparan di dinding luar flume, (5) Untuk perubahan kecepatan arus, dan bentuk model yang lain, simulasi dimulai dari langkah (1). 


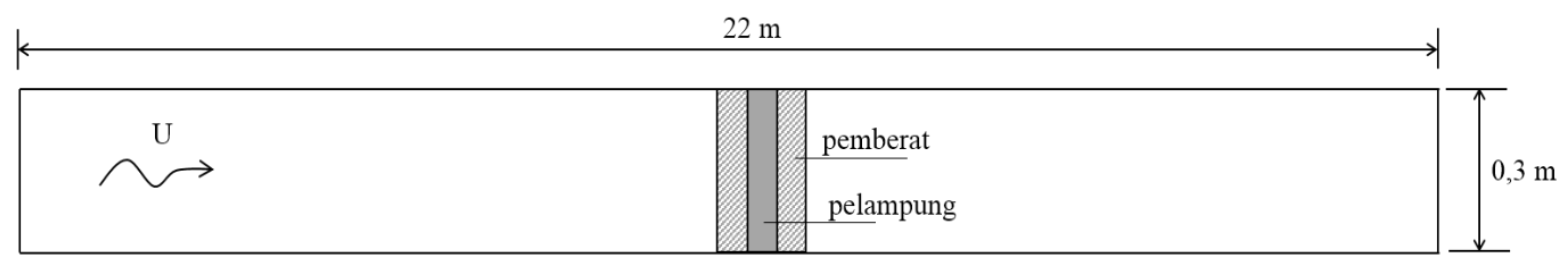

a. Tampak Atas

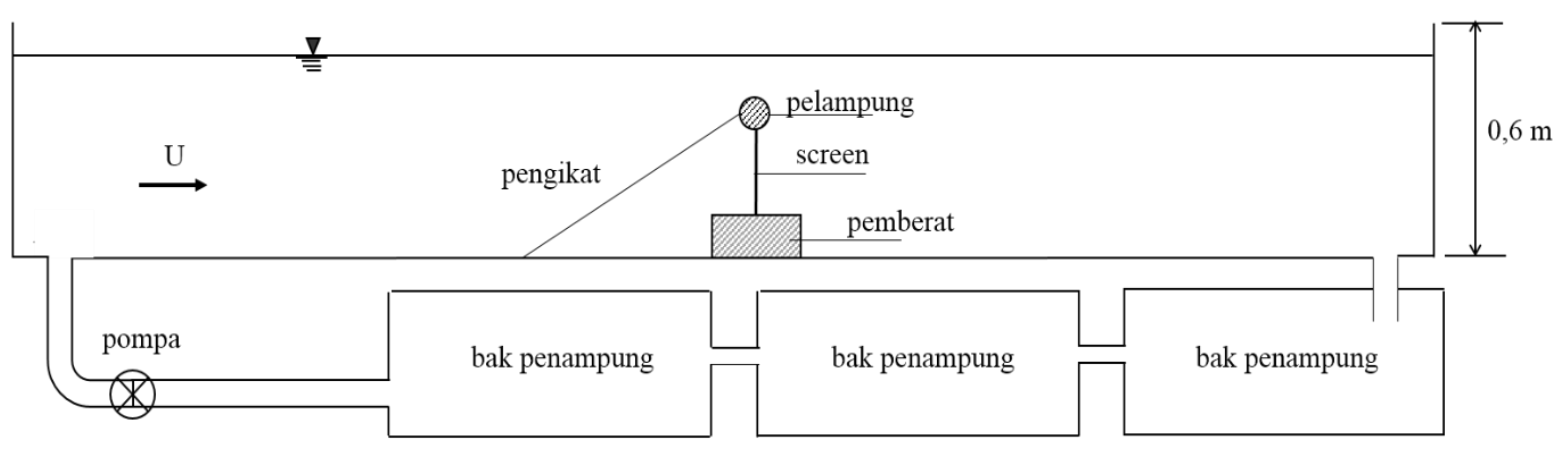

b. Tampak Samping

Gambar 3. Glass Sided Fixed Bed Tilting Flume

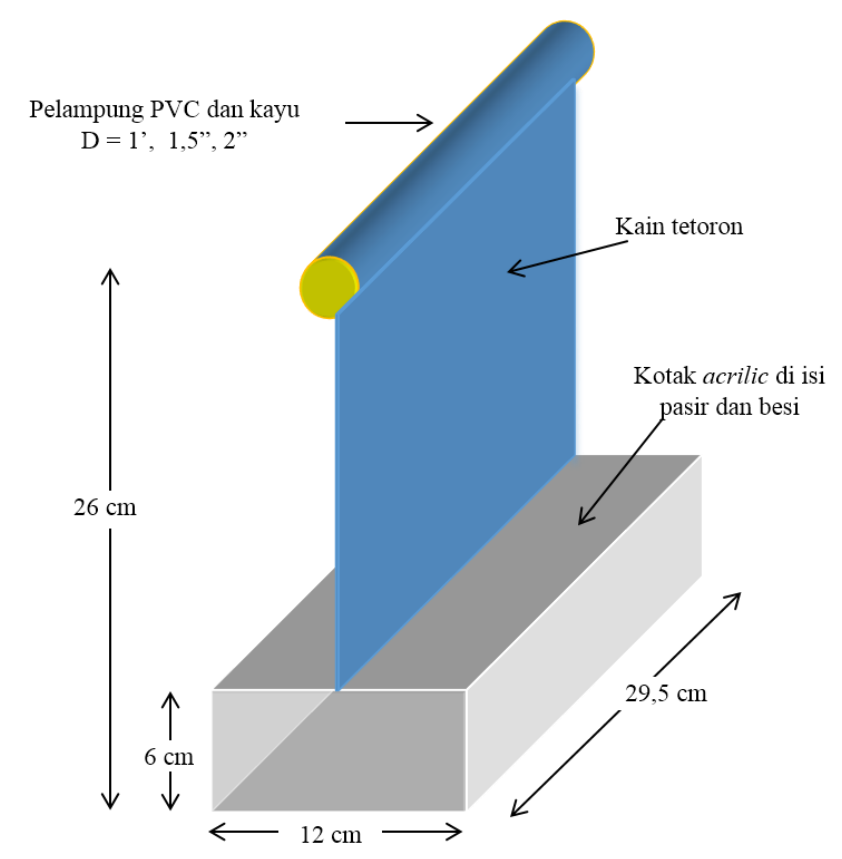

Gambar 4. Profil Model Silt Screen 
Tabel 1. Variasi Simulasi Simpangan Silt Screen

\begin{tabular}{|c|c|c|c|c|c|c|}
\hline No & Simulasi & $\begin{array}{c}\text { Kedalaman } \\
\text { relatif } \\
\text { h/d }\end{array}$ & $\begin{array}{l}\text { Debit aliran (Q) } \\
(\mathrm{m} / \mathrm{dt})\end{array}$ & $\begin{array}{c}\text { Diameter (D) } \\
(\mathrm{m})\end{array}$ & Pelampung & Sketsa Model \\
\hline 1 & A & 1 & $\begin{array}{l}0,0216 ; 0,0247 ; \\
0,0267 ; 0,0268\end{array}$ & \multirow{2}{*}{0,0254} & \multirow{2}{*}{$\begin{array}{c}\text { tanpa } \\
\text { pengikatan }\end{array}$} & \multirow[t]{2}{*}{$C$} \\
\hline 2 & B & 0,87 & $\begin{array}{c}0,0219 ; 0,0245 \\
0,0255 ; 0,0268\end{array}$ & & & \\
\hline 3 & C & 1 & $\begin{array}{l}0,0216 ; 0,0247 \\
0,0267 ; 0,0268\end{array}$ & \multirow{2}{*}{0,0381} & \multirow{2}{*}{$\begin{array}{c}\text { tanpa } \\
\text { pengikatan }\end{array}$} & \\
\hline 4 & D & 0,87 & $\begin{array}{c}0,0219 ; 0,0245 ; \\
0,0255 ; 0,0268\end{array}$ & & & \\
\hline 5 & E & 1 & $\begin{array}{l}0,0216 ; 0,0247 \\
0,0267 ; 0,0268\end{array}$ & \multirow{2}{*}{0,0508} & \multirow{2}{*}{$\begin{array}{c}\text { tanpa } \\
\text { pengikatan }\end{array}$} & \\
\hline 6 & $\mathrm{~F}$ & 0,87 & $\begin{array}{c}0,0219 ; 0,0245 ; \\
0,0255 ; 0,0268\end{array}$ & & & \\
\hline 7 & G & 1 & $\begin{array}{l}0,0216 ; 0,0247 \\
0,0267 ; 0,0268\end{array}$ & \multirow{2}{*}{0,0254} & \multirow{2}{*}{$\begin{array}{c}\text { dengan } \\
\text { pengikatan }\end{array}$} & \\
\hline 8 & $\mathrm{H}$ & 0,87 & $\begin{array}{c}0,0219 ; 0,0245 ; \\
0,0255 ; 0,0268\end{array}$ & & & \\
\hline 9 & I & 1 & $\begin{array}{l}0,0216 ; 0,0247 \\
0,0267 ; 0,0268\end{array}$ & \multirow{2}{*}{0,0381} & \multirow{2}{*}{$\begin{array}{c}\text { dengan } \\
\text { pengikatan }\end{array}$} & \\
\hline 10 & $\mathrm{~J}$ & 0,87 & $\begin{array}{c}0,0219 ; 0,0245 ; \\
0,0255 ; 0,0268\end{array}$ & & & \\
\hline 11 & $\mathrm{~K}$ & 1 & $\begin{array}{l}0,0216 ; 0,0247 \\
0,0267 ; 0,0268\end{array}$ & \multirow{2}{*}{0,0508} & \multirow{2}{*}{$\begin{array}{c}\text { dengan } \\
\text { pengikatan }\end{array}$} & \\
\hline 12 & $\mathrm{~L}$ & 0,87 & $\begin{array}{c}0,0219 ; 0,0245 ; \\
0,0255 ; 0,0268\end{array}$ & & & \\
\hline
\end{tabular}

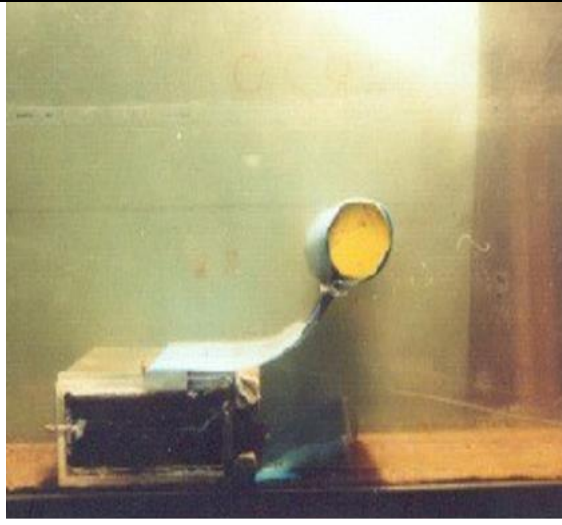

a. Tampak Samping

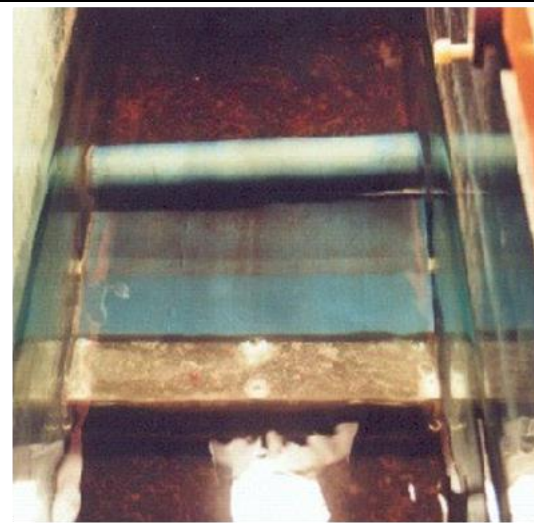

b. Tampak Atas

Gambar 5. Simulasi simpangan Slit Screen Tanpa Pengikatan Pelampung 


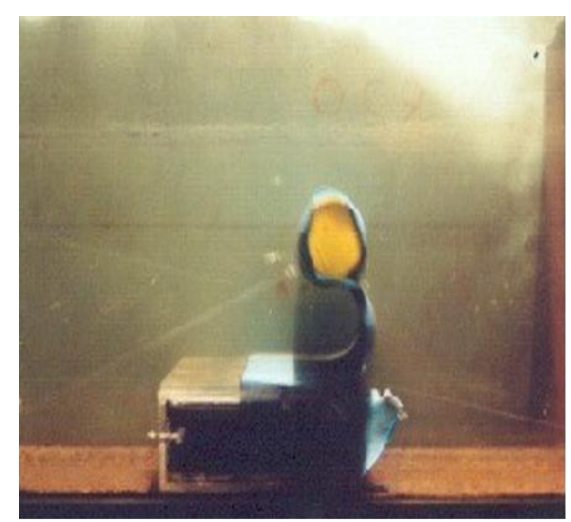

a. Tampak Samping

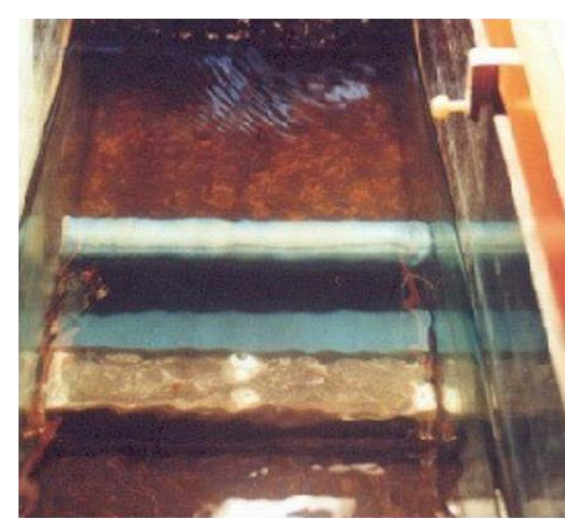

b. Tampak Atas

Gambar 6. Simulasi simpangan Slit Screen Dengan Pengikatan Pelampung

\section{HASIL DAN PEMBAHASAN}

\subsection{Pengaruh Gaya Vertikal dan Gaya Arus}

Semakin besar gaya arus $\left(\mathrm{F}_{\mathrm{U}}\right)$, maka simpangan yang terjadi semakin besar dan efisiensi semakin kecil untuk pelampung tanpa pengikatan, nilai koefisien drag $(\mathrm{Cd})$ yang digunakan untuk menghitung gaya arus $\left(\mathrm{F}_{\mathrm{U}}\right)$ dari hasil penelitian Bangguna $(2013)$ [1]. Sebaliknya pelampung dengan pengikatan pelampung, semakin besar gaya arus simpangan yang terjadi kecil, dan efisiensi besar. Pelampung dari PVC yang tertutup ujungnya, memberikan pengapungan yang lebih baik, sehingga tirai silt screen akan lebih tegak dibandingkan dengan pelampung kayu saat terkena arus. Kondisi ini akan menghasilkan simpangan silt screen yang lebih pendek dan efisiensi yang lebih besar untuk pelampung PVC dibandingkan menggunakan pelampung kayu.

Pelampung yang berat akan menyebabkan perubahan tinggi silt screen setelah terkena arus (h') menjadi rendah saat terkena arus. Kondisi ini akan mengakibatkan silt screen tidak berfungsi maksimal dalam menjaring sedimen. Profil simpangan silt screen hasil simulasi tanpa dan dengan pengikatan pelampung dapat dilihat dalam Gambar 7. Hasil analisis simpangan dan efisiensi silt screen tanpa pengikatan pelampung dapat dilihat dalam Tabel 2 dan Gambar 8. Pelampung dengan pengikatan dapat dilihat dalam Tabel 3 dan Gambar 9 berikut. 


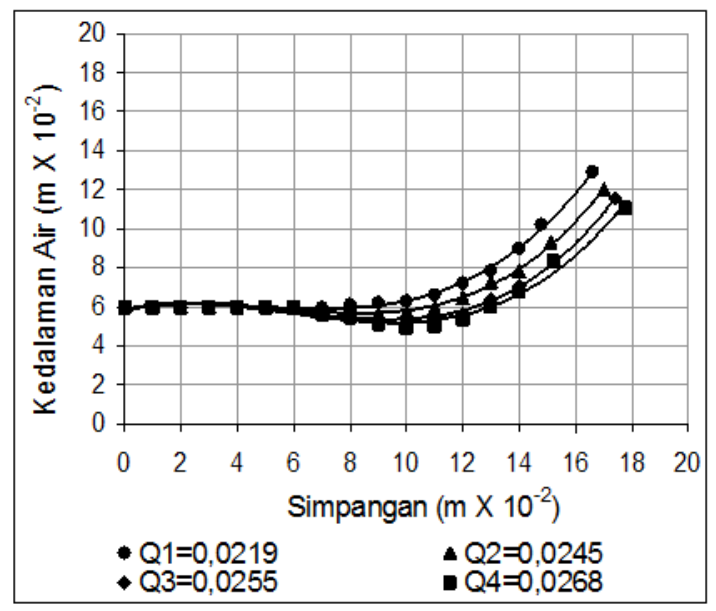

Silt screen dengan pelampung D 1"

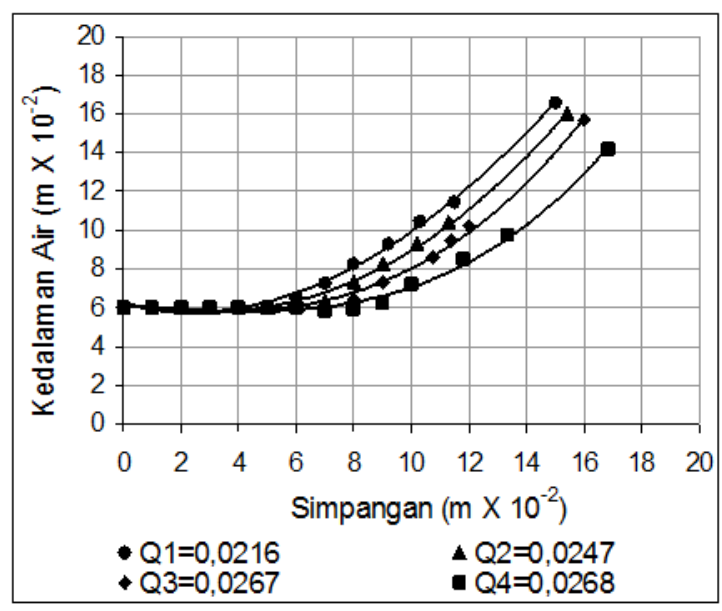

Silt screen dengan pelampung D 2"

a. Tanpa Pengikatan Pelampung

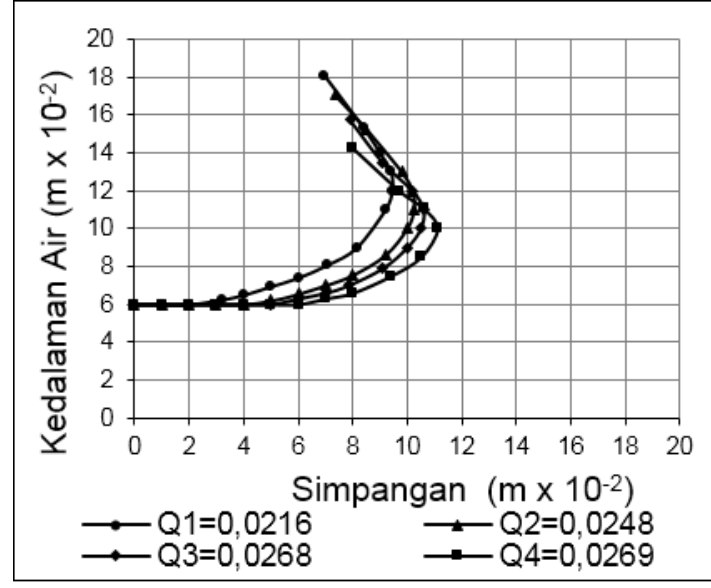

Silt screen dengan pelampung D 1"

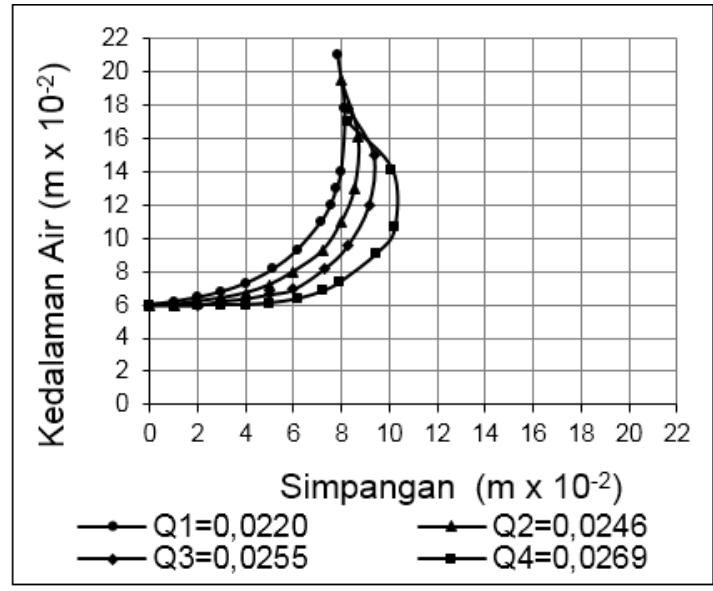

Silt screen dengan pelampung D 2"

b. Dengan Pengikatan Pelampung

Gambar 7. Profil Simpangan Silt Screen

Tabel 2. Analisis Simpangan dan Efisiensi Silt Screen Tanpa Pengikatan Pelampung

\begin{tabular}{|c|c|c|c|c|c|c|}
\hline Pelampung & $\begin{array}{l}\text { Kedalaman relatif } \\
\text { (h/d) }\end{array}$ & $\begin{array}{l}\text { Gaya vertikal (Fv) } \\
\text { (N) }\end{array}$ & $\begin{array}{l}\text { Gaya arus }\left(\mathrm{F}_{\mathrm{U}}\right) \\
(\mathrm{N})\end{array}$ & $\mathrm{Fv} / \mathrm{F}_{\mathrm{U}}$ & $\begin{array}{c}\text { Simpangan } \\
\text { silt screen } \\
(\%)\end{array}$ & $\begin{array}{l}\text { Efisiensi } \\
\text { silt screen } \\
(\%)\end{array}$ \\
\hline \multirow{22}{*}{ PVC } & \multirow{12}{*}{1} & 0,0759 & 0,1226 & 0,62 & 64,04 & 48,08 \\
\hline & & 0,0759 & 0,1290 & 0,59 & 65,77 & 47,12 \\
\hline & & 0,0759 & 0,1678 & 0,45 & 66,15 & 42,88 \\
\hline & & 0,0759 & 0,2714 & 0,28 & 68,27 & 41,73 \\
\hline & & 1,4270 & 1,3277 & 1,07 & 63,08 & 55,77 \\
\hline & & 1,4270 & 1,3702 & 1,04 & 64,62 & 52,12 \\
\hline & & 1,4270 & 1,5517 & 0,92 & 65,38 & 50,00 \\
\hline & & 1,4270 & 1,8752 & 0,76 & 66,15 & 46,15 \\
\hline & & 3,6616 & 3,1471 & 1,16 & 55,77 & 65,38 \\
\hline & & 3,6616 & 3,5472 & 1,03 & 57,69 & 62,69 \\
\hline & & 3,6616 & 3,9135 & 0,94 & 60,00 & 60,38 \\
\hline & & 3,6616 & 4,0364 & 0,91 & 61,54 & 58,08 \\
\hline & \multirow{10}{*}{0,87} & 0,0759 & 0,0485 & 1,57 & 61,54 & 56,54 \\
\hline & & 0,0759 & 0,0568 & 1,34 & 63,46 & 53,85 \\
\hline & & 0,0759 & 0,0598 & 1,27 & 64,42 & 53,08 \\
\hline & & 0,0759 & 0,0670 & 1,13 & 64,81 & 50,00 \\
\hline & & 1,4270 & 1,0349 & 1,38 & 54,23 & 65,38 \\
\hline & & 1,4270 & 1,1035 & 1,29 & 57,69 & 61,54 \\
\hline & & 1,4270 & 1,0646 & 1,34 & 59,62 & 59,62 \\
\hline & & 1,4270 & 1,1901 & 1,20 & 61,54 & 55,77 \\
\hline & & 3,6616 & 2,4691 & 1,48 & 50,00 & 71,92 \\
\hline & & 3,6616 & 2,7328 & 1,34 & 53,85 & 68,65 \\
\hline
\end{tabular}




\begin{tabular}{|c|c|c|c|c|c|c|}
\hline Pelampung & $\begin{array}{l}\text { Kedalaman relatif } \\
(\mathrm{h} / \mathrm{d})\end{array}$ & $\begin{array}{l}\text { Gaya vertikal }(\mathrm{Fv}) \\
(\mathrm{N})\end{array}$ & $\begin{array}{c}\text { Gaya } \underset{(\mathrm{N})}{\operatorname{arus}}\left(\mathrm{F}_{\mathrm{U}}\right) \\
\end{array}$ & $\mathrm{Fv} / \mathrm{F}_{\mathrm{U}}$ & $\begin{array}{c}\text { Simpangan } \\
\text { silt screen } \\
(\%)\end{array}$ & $\begin{array}{c}\text { Efisiensi } \\
\text { silt screen } \\
(\%)\end{array}$ \\
\hline & & 3,6616 & 3,1150 & 1,18 & 55,58 & 67,69 \\
\hline & & 3,6616 & 3,3573 & 1,09 & 57,69 & 66,35 \\
\hline \multirow{24}{*}{ Kayu } & \multirow{12}{*}{1} & 0,0033 & 0,0040 & 0,004 & 65,38 & 40,77 \\
\hline & & 0,0033 & 0,0069 & 0,007 & 67,69 & 37,12 \\
\hline & & 0,0033 & 0,0053 & 0,005 & 70,38 & 33,46 \\
\hline & & 0,0033 & 0,0050 & 0,005 & 72,69 & 30,19 \\
\hline & & 0,0104 & 0,0133 & 0,013 & 64,62 & 44,62 \\
\hline & & 0,0104 & 0,0159 & 0,016 & 66,73 & 40,96 \\
\hline & & 0,0104 & 0,0188 & 0,019 & 67,69 & 37,31 \\
\hline & & 0,0104 & 0,0162 & 0,016 & 68,65 & 35,38 \\
\hline & & 0,2527 & 0,2587 & 0,259 & 64,62 & 63,85 \\
\hline & & 0,2527 & 0,2635 & 0,263 & 66,73 & 61,54 \\
\hline & & 0,2527 & 0,2769 & 0,277 & 67,69 & 60,38 \\
\hline & & 0,2527 & 0,3754 & 0,375 & 68,65 & 54,62 \\
\hline & \multirow{12}{*}{0,87} & 0,0033 & 0,0035 & 0,004 & 63,85 & 49,62 \\
\hline & & 0,0033 & 0,0057 & 0,006 & 65,38 & 46,15 \\
\hline & & 0,0033 & 0,0072 & 0,007 & 66,92 & 44,42 \\
\hline & & 0,0033 & 0,0072 & 0,007 & 68,27 & 42,50 \\
\hline & & 0,0104 & 0,0103 & 0,010 & 60,00 & 38,46 \\
\hline & & 0,0104 & 0,0104 & 0,010 & 61,35 & 54,23 \\
\hline & & 0,0104 & 0,0110 & 0,011 & 61,54 & 52,31 \\
\hline & & 0,0104 & 0,0112 & 0,011 & 64,42 & 48,46 \\
\hline & & 0,2527 & 0,2235 & 0,224 & 53,46 & 65,38 \\
\hline & & 0,2527 & 0,2376 & 0,238 & 56,73 & 64,62 \\
\hline & & 0,2527 & 0,2676 & 0,268 & 59,42 & 63,46 \\
\hline & & 0,2527 & 0,2916 & 0,292 & 61,54 & 61,54 \\
\hline
\end{tabular}

Tabel 3. Analisis Simpangan dan Efisiensi Silt Screen Dengan Pengikatan Pelampung

\begin{tabular}{|c|c|c|c|c|c|c|}
\hline Pelampung & $\begin{array}{l}\text { Kedalaman } \\
\text { relatif } \\
(\mathrm{h} / \mathrm{d})\end{array}$ & $\begin{array}{l}\text { Gaya vertikal }(\mathrm{Fv}) \\
(\mathrm{N})\end{array}$ & $\begin{array}{c}\text { Gaya arus }\left(F_{U}\right) \\
(\mathrm{N})\end{array}$ & $\mathrm{Fv} / \mathrm{F}_{\mathrm{U}}$ & $\begin{array}{c}\text { Simpangan } \\
\text { silt screen } \\
(\%)\end{array}$ & $\begin{array}{c}\text { Efisiensi } \\
\text { silt screen } \\
(\%)\end{array}$ \\
\hline \multirow{24}{*}{ PVC } & \multirow{12}{*}{1} & 0,0759 & 0,2283 & 0,33 & 26,73 & 69,62 \\
\hline & & 0,0759 & 0,2281 & 0,33 & 28,27 & 65,58 \\
\hline & & 0,0759 & 0,3178 & 0,24 & 30,38 & 60,58 \\
\hline & & 0,0759 & 0,4616 & 0,16 & 30,77 & 54,81 \\
\hline & & 1,4270 & 1,9837 & 0,72 & 23,85 & 71,92 \\
\hline & & 1,4270 & 2,1415 & 0,67 & 25,38 & 68,46 \\
\hline & & 1,4270 & 2,3164 & 0,62 & 27,88 & 63,27 \\
\hline & & 1,4270 & 2,7190 & 0,52 & 29,42 & 56,54 \\
\hline & & 3,6616 & 3,9339 & 0,93 & 28,85 & 75,96 \\
\hline & & 3,6616 & 4,1671 & 0,88 & 31,73 & 69,62 \\
\hline & & 3,6616 & 4,4380 & 0,83 & 32,88 & 65,38 \\
\hline & & 3,6616 & 4,4356 & 0,83 & 33,85 & 61,54 \\
\hline & \multirow{12}{*}{0,87} & 0,0759 & 0,0744 & 1,02 & 25,96 & 74,42 \\
\hline & & 0,0759 & 0,0860 & 0,88 & 26,92 & 69,62 \\
\hline & & 0,0759 & 0,0786 & 0,97 & 28,65 & 62,50 \\
\hline & & 0,0759 & 0,0875 & 0,87 & 29,81 & 58,27 \\
\hline & & 1,4270 & 1,3172 & 1,08 & 21,15 & 76,92 \\
\hline & & 1,4270 & 1,4345 & 0,99 & 22,50 & 73,08 \\
\hline & & 1,4270 & 1,3280 & 1,07 & 23,65 & 68,65 \\
\hline & & 1,4270 & 1,4841 & 0,96 & 26,15 & 63,85 \\
\hline & & 3,6616 & 3,0912 & 1,18 & 22,31 & 84,23 \\
\hline & & 3,6616 & 3,2748 & 1,12 & 25,77 & 77,69 \\
\hline & & 3,6616 & 3,3835 & 1,08 & 28,27 & 71,54 \\
\hline & & 3,6616 & 3,2827 & 1,12 & 30,77 & 65,38 \\
\hline \multirow{14}{*}{ Kayu } & \multirow{12}{*}{1} & 0,0033 & 0,0091 & 0,36 & 26,92 & 63,46 \\
\hline & & 0,0033 & 0,0187 & 0,18 & 28,27 & 60,96 \\
\hline & & 0,0033 & 0,0173 & 0,19 & 30,00 & 57,12 \\
\hline & & 0,0033 & 0,0215 & 0,15 & 30,19 & 53,85 \\
\hline & & 0,0104 & 0,0273 & 0,38 & 22,88 & 67,31 \\
\hline & & 0,0104 & 0,0342 & 0,30 & 25,38 & 61,54 \\
\hline & & 0,0104 & 0,0457 & 0,23 & 25,96 & 57,69 \\
\hline & & 0,0104 & 0,0420 & 0,25 & 28,08 & 55,00 \\
\hline & & 0,2527 & 0,3124 & 0,81 & 27,69 & 72,31 \\
\hline & & 0,2527 & 0,3030 & 0,83 & 29,81 & 67,31 \\
\hline & & 0,2527 & 0,3040 & 0,83 & 31,15 & 64,04 \\
\hline & & 0,2527 & 0,4326 & 0,58 & 31,73 & 59,42 \\
\hline & \multirow{2}{*}{0,87} & 0,0033 & 0,0061 & 0,54 & 22,50 & 69,04 \\
\hline & & 0,0033 & 0,0107 & 0,31 & 23,88 & 65,96 \\
\hline
\end{tabular}




\begin{tabular}{|c|c|c|c|c|c|c|}
\hline Pelampung & $\begin{array}{c}\text { Kedalaman } \\
\text { relatif } \\
(\mathrm{h} / \mathrm{d})\end{array}$ & $\begin{array}{c}\text { Gaya vertikal (Fv) } \\
(\mathrm{N})\end{array}$ & $\begin{array}{l}\text { Gaya } \underset{(\mathrm{N})}{\operatorname{arus}}\left(\mathrm{F}_{\mathrm{U}}\right) \\
\end{array}$ & $\mathrm{Fv} / \mathrm{F}_{\mathrm{U}}$ & $\begin{array}{l}\text { Simpangan } \\
\text { silt screen } \\
(\%)\end{array}$ & $\begin{array}{c}\text { Efisiensi } \\
\text { silt screen } \\
(\%)\end{array}$ \\
\hline & & 0,0033 & 0,0128 & 0,26 & 25,96 & 60,77 \\
\hline & & 0,0033 & 0,0125 & 0,26 & 27,54 & 57,12 \\
\hline & & 0,0104 & 0,0330 & 0,32 & 23,46 & 72,31 \\
\hline & & 0,0104 & 0,0147 & 0,71 & 25,19 & 66,92 \\
\hline & & 0,0104 & 0,0152 & 0,68 & 26,15 & 63,46 \\
\hline & & 0,0104 & 0,0155 & 0,67 & 26,92 & 58,27 \\
\hline & & 0,2527 & 0,2804 & 0,90 & 26,35 & 76,15 \\
\hline & & 0,2527 & 0,2673 & 0,95 & 27,88 & 69,81 \\
\hline & & 0,2527 & 0,2817 & 0,90 & 30,38 & 65,58 \\
\hline & & 0,2527 & 0,2975 & 0,85 & 29,81 & 62,31 \\
\hline
\end{tabular}
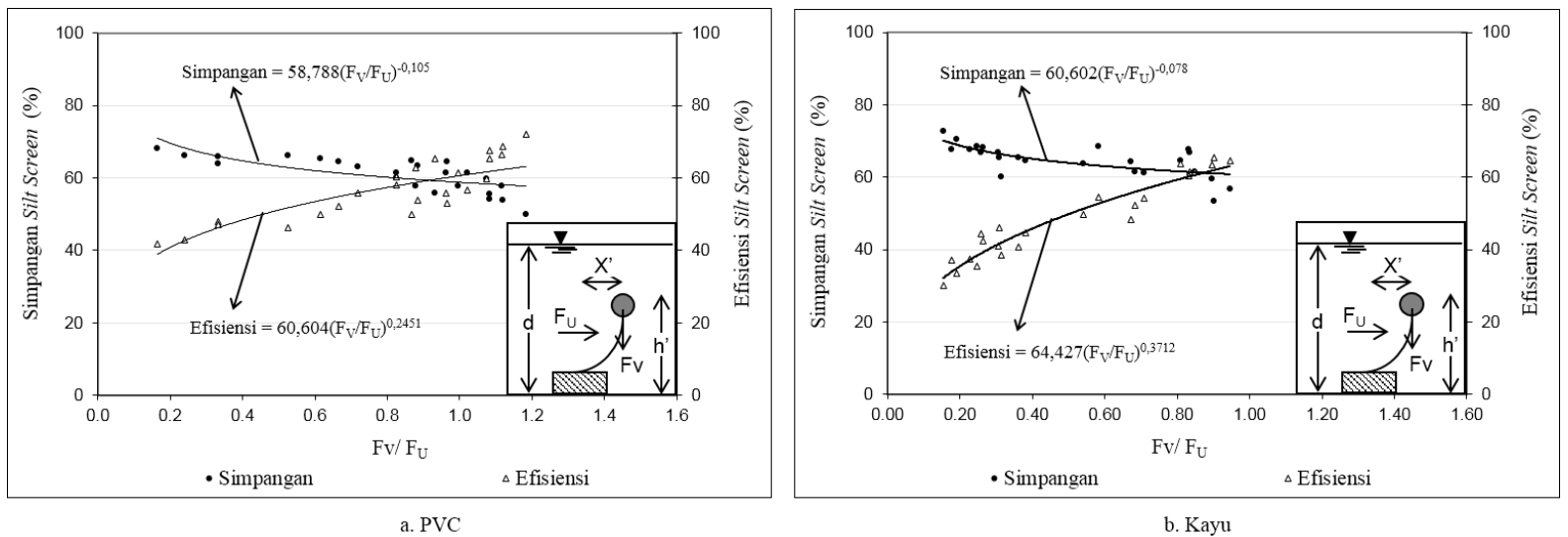

Gambar 8. Persentase Simpangan dan Efisiensi Silt Screen Tanpa Pengikatan Pelampung
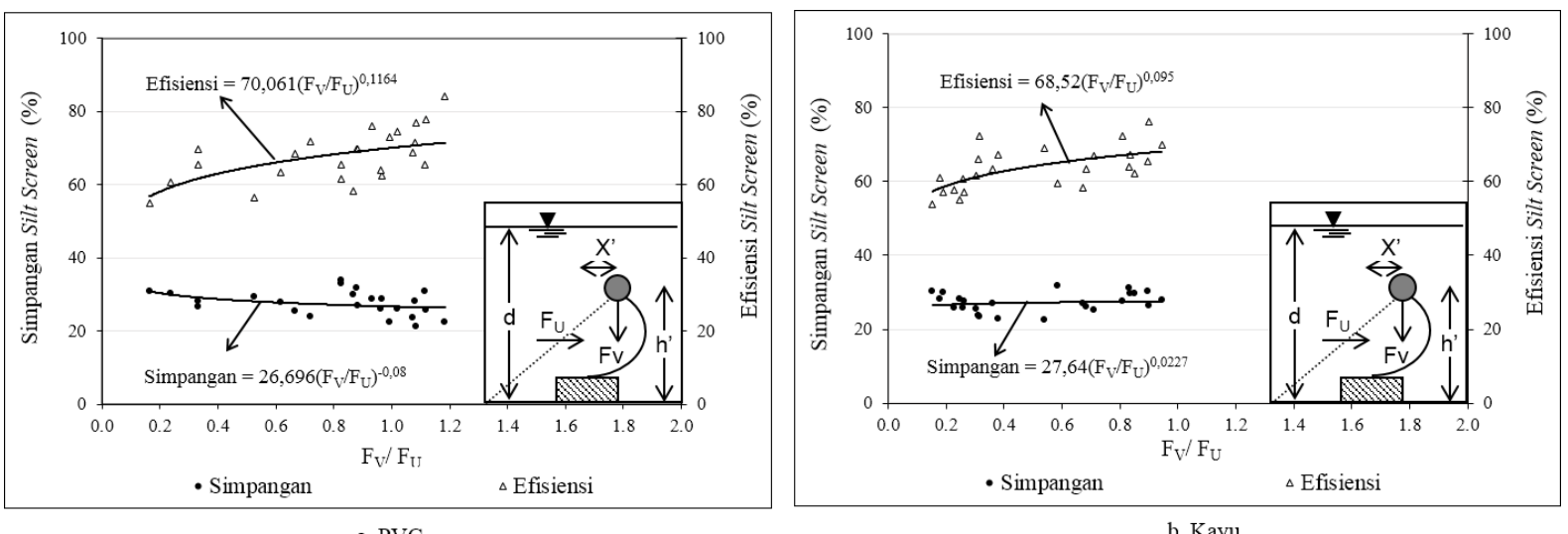

Gambar 9. Persentase Simpangan dan Efisiensi Silt Screen Dengan Pengikatan Pelampung

\subsection{Pengaruh Pengikatan Pelampung}

Gambar 9 di atas menunjukkan pengaruh pengikatan pelampung, pengikatan pelampung akan memperkecil simpangan dan menambah efisiensi silt screen. Pengikatan pelampung harus diperhatikan bahan pelampungnya. Pelampung terlalu berat maka perubahan tinggi silt screen arah vertikal (h') akan sangat rendah saat diterjang gaya arus ( $\mathrm{F}_{\mathrm{U}}$ ) yang cukup besar, sehingga sedimen yang akan dijaring oleh silt screen akan lolos ke kolam labuh. Hubungan antara efisiensi terhadap perbandingan simpangan (X') dan perubahan tinggi silt screen setelah terkena arus (h') dari hasil simulasi secara teoritis hampir mendekati sama (Gambar 10). 


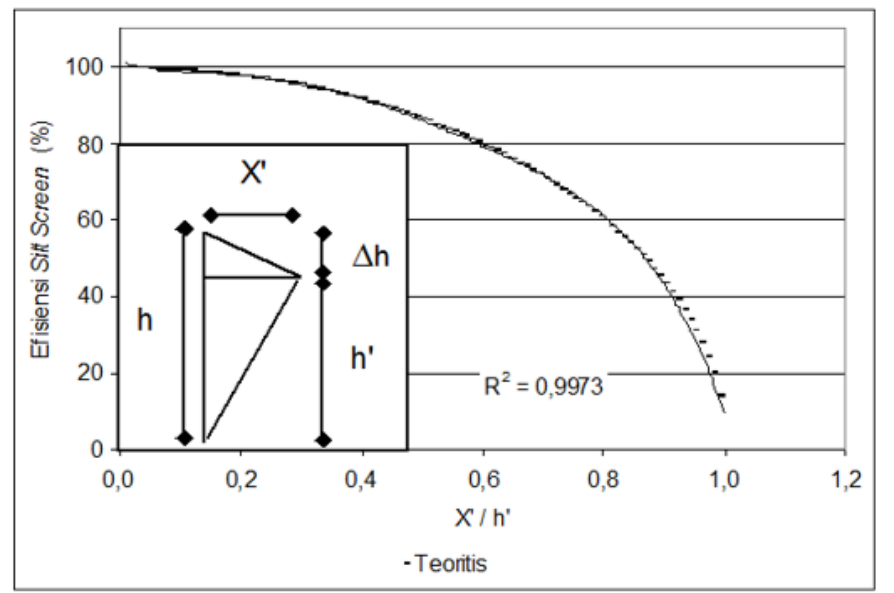

Gambar 10. Pengaruh Pengikatan Pelampung Terhadap Efisiensi Teoritis dan Pengukuran

\section{KESIMPULAN}

Untuk pengujian dengan kedalaman relatif $(\mathrm{h} / \mathrm{d})$ dan gaya apung pelampung $\left(\mathrm{F}_{\mathrm{BP}}\right)$ yang sama, menunjukkan bahwa semakin besar kecepatan arus (U) maka simpangan yang terjadi semakin besar dan efisiensi semakin kecil. Dengan semakin besarnya simpangan maka luas proyeksi silt screen $\left(\mathrm{A}_{\mathrm{P}}\right)$ semakin kecil, sehingga gaya arus $\left(\mathrm{F}_{\mathrm{U}}\right)$ yang bekerja pada silt screen juga menjadi kecil.

Pengikatan pada pelampung akan memperkecil simpangan silt screen dan menambah efisiensi dalam menjaring sedimen yang terbawa oleh arus. Pelampung tanpa pengikatan, simpangannya 50,00\% sampai dengan 72,69\%, dengan efisiensi 30,19\% sampai dengan $71,92 \%$. Pelampung dengan pengikatan, simpangan yang terjadi $21,15 \%$ sampai dengan $33,85 \%$, dengan efisiensi $53,85 \%$ sampai dengan $84,23 \%$.

Dari pengujian pelampung tanpa pengikatan maupun dengan pengikatan, simpangan dan efisiensi silt screen yang dihasilkan bahan pelampung paralon memberikan hasil yang lebih baik dari pada bahan kayu. Lebih baiknya hasil yang diberikan oleh bahan pelampung paralon ini karena sifat $\operatorname{PCV}(\gamma)$ lebih ringan daripada sifat kayu sehingga gaya vertikal (Fv) yang bekerja pada pelampung PCV lebih besar daripada pelampung kayu. Dengan lebih besarnya gaya vertikal maka simpangan yang terjadi semakin kecil dan efisiensi yang terjadi semakin besar.

\section{DAFTAR PUSTAKA}

[1] D. S. V. L. Bangguna, "Besarnya Koefisien Hambat (CD) Silt Screen Akibat Gaya Arus Dengan Model Pelampung Paralon Dan Kayu," J. Maroso, vol. 1, no. 01, 2013. pp18-21

[2] M. Radermacher, L. de Wit, J. C. Winterwerp, and W. S. J. Uijttewaal, "Efficiency of hanging silt curtains in crossflow," J. Waterw. Port, Coast. Ocean Eng., vol. 142, no. 1, 2016, doi: 10.1061/(ASCE)WW.1943-5460.0000315. pp 19-23

[3] F. Aschmoneit, J. Hjelmager Jensen, S. Saremi, and C. Hélix-Nielsen, "Fluxes of Sediment Beneath Floating Silt Screens due to Density Gradients and Screen Motion," J. Waterw. Port, Coast. Ocean Eng., vol. 146, no. 4, 2020, doi: 10.1061/(ASCE)WW.1943-5460.0000568. pp13-15

[4] J.-Y. Jin et al., "Behavior of Currents and Suspended Sediments around a Silt Screen," Ocean and Polar Research, vol. 25, no. spc3. pp. 399-408, 2003, doi: 10.4217/opr.2003.25.spc3.399.

[5] T. T. Vu and S. K. Tan, "Laboratory investigation of hydraulic performance of silt screens," J. Hydrodyn., vol. 22, no. 5 SUPPL. 1, pp. 312-317, 2010, doi: 10.1016/S1001-6058(09)60212-2.

[6] M. Radermacher, F. van der Goot, D. C. Rijks, and L. de Wit, "The art of screening, effectiveness of silt screens," Proc. WODCON XX - Congr. Exhib. Art Dredg., pp. 3-12, 2013. 